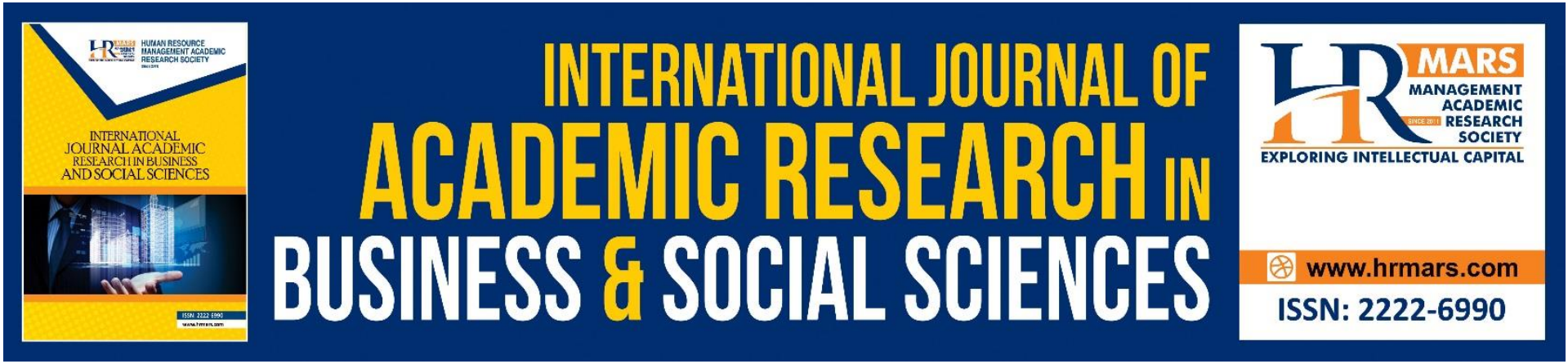

\title{
A Preliminary Study on the Slope Failure at Highlands in Peninsular Malaysia
}

\author{
M. Danish Zabidi, B.A. Hadi, Amir K.R., R. Keria, A. Derahman
}

To Link this Article: http://dx.doi.org/10.6007/IJARBSS/v11-i4/9702 DOI:10.6007/IJARBSS/v11-i4/9702

Received: 02 February 2021, Revised: 06 March 2021, Accepted: 01 April 2021

Published Online: 20 April 2021

In-Text Citation: (Zabidi et al., 2021)

To Cite this Article: Zabidi, M. D., Hadi, B. A., K.R., A., Keria, R., \& Derahman, A. (2021). A Preliminary Study on the Slope Failure at Highlands in Peninsular Malaysia. International Journal of Academic Research in Business and Social Sciences, 11(4), 585-594.

Copyright: (c) 2021 The Author(s)

Published by Human Resource Management Academic Research Society (www.hrmars.com)

This article is published under the Creative Commons Attribution (CC BY 4.0) license. Anyone may reproduce, distribute, translate and create derivative works of this article (for both commercial and non-commercial purposes), subject to full attribution to the original publication and authors. The full terms of this license may be seen

at: http://creativecommons.org/licences/by/4.0/legalcode

Vol. 11, No. 4, 2021, Pg. 585 - 594

http://hrmars.com/index.php/pages/detail/IJARBSS

JOURNAL HOMEPAGE

Full Terms \& Conditions of access and use can be found at http://hrmars.com/index.php/pages/detail/publication-ethics 


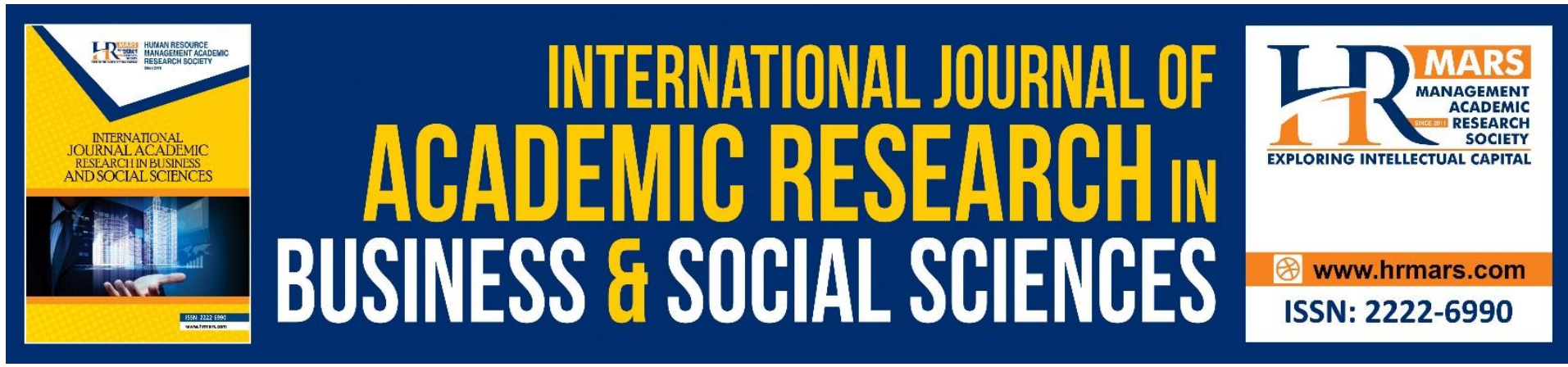

\title{
A Preliminary Study on the Slope Failure at Highlands in Peninsular Malaysia
}

\author{
M. Danish Zabidi, B.A. Hadi, Amir K.R., R. Keria, A. Derahman \\ Faculty of Civil Engineering, Universiti Teknologi Mara Malaysia \\ Email: danishzabd@gmail.com
}

\begin{abstract}
Cases of landslides occurrences in the time of intense rainfall were reported throughout the years especially at Highlands in Peninsular Malaysia. Infiltration of rainwater caused various moisture content in soil of slope resulted in these landslides. Thus, this study was performed to evaluate the moisture content of residual soil on slope at Kampung Raja, Cameron Highlands. The objectives were to collect and label the soil samples, analyze the moisture content in laboratory, then evaluate them with an existing model. Soil samples were collected at 10 different locations by digging between 0.2 to 0.5 meters deep, placing the soil into plastic containers, and weight them. The containers were labelled with individual number sequence, weight, date, and time of sampling. The coordinates and surrounding temperatures of each samples were also recorded by utilizing software in smartphone i.e., Google Maps and Weather application. By referring to BS 1337: Part 2: 1990, the determination of moisture content was performed using oven-drying method in laboratory. The soil located on a slope at Kampung Raja, Cameron Highlands had moisture content between $24.1 \%$ to $38.5 \%$ with an average of $27.6 \%$. The results were evaluated with Soil Water Characteristic Curve and was found that the soil had potential risk for future landslide. The results of this study could be used to correlate with the water suction property of the soil.
\end{abstract}

Keywords: Landslide, Highlands, Rainfall, Moisture Content, Oven-Dry

\section{Introduction}

The first landslide was reported back in 1961 which took place in Ringlet, Cameron Highland (Maturidi et al., 2020). Ever since then, cases of major landslides occurrences were reported to happen in Cameron Highlands at least twice every year. An example of former landslide site was at Kampung Raja, Cameron Highlands which happened on October 2018 (Maturidi et al., 2020) as in Figure 1. Retaining structure were constructed to resist future soil movement as in Figure 2. Latest report by Rosman (2020) confirmed a case of landslide occurred on $1^{\text {st }}$ of October in three different location which were Batu 12, Batu 18, and Batu 24. Although these landslides took place in different times and locations, according to reports heavy rainfall occurred in all these events. 


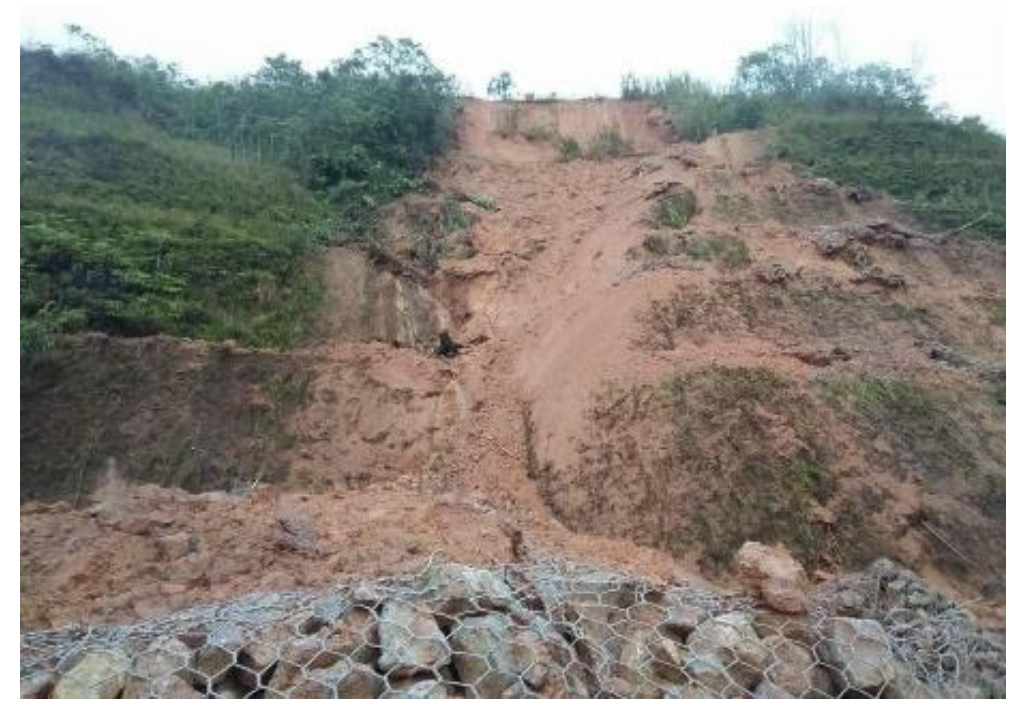

Figure 1. Photo of lanslide in $\mathbf{2 0 1 8}$ at Kampung Raja, Cameron Highlands

(Source: Suara Perak, 2018)

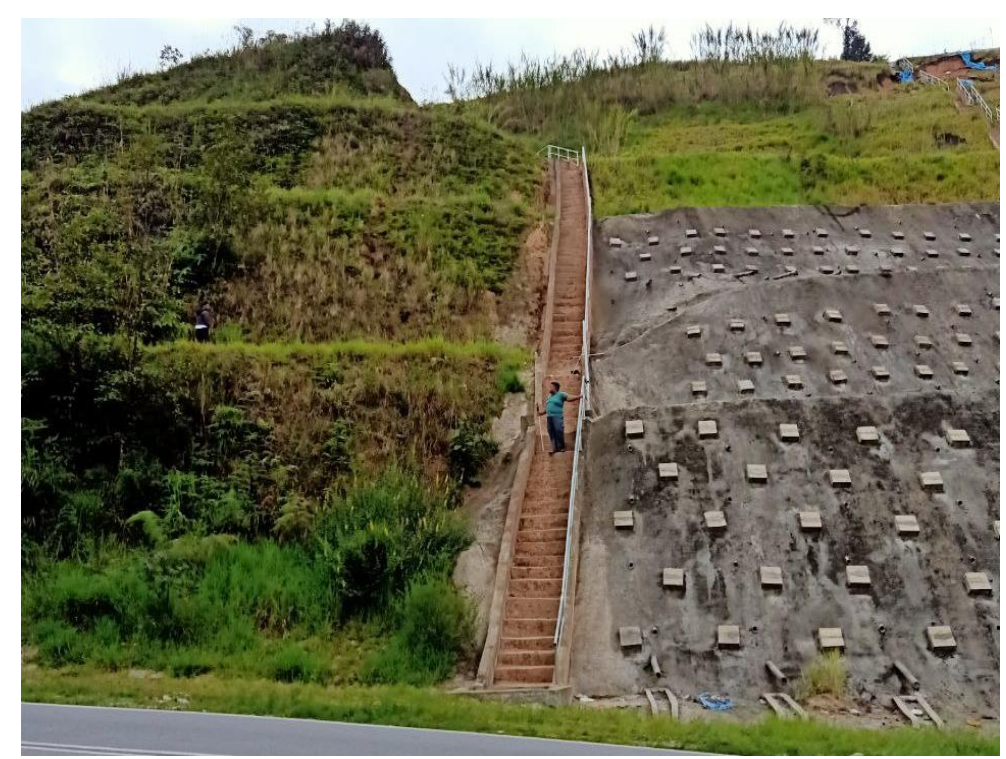

Figure 2. Photo of the site on October 2020

Previous studies confirmed the cause of these landslides were due to intense rainfall. Thus, this research was done to predict the soil strength of a previous landslide spot which took place in Kampung Raja, Cameron Highlands. This research was focused to collect soil samples, label and analyze them through moisture content analysis, then to evaluate the results, an existing model would be used. 


\section{Literature Review}

Malaysia had many highlands destinations that offered place to rest and relax, each had their own kind of attractions. One highland in particular was the Cameron Highlands located in Pahang, Malaysia. Cameron Highlands was popular for its tea plantations. Pua et al. (2020) indicated $47 \%$ of the Pahang land were allocated for tea plantation. They also added that the leading tea production in Malaysia was done by $\mathrm{BOH}$ Plantations. Another attraction spot mentioned by Aziz et al. (2020) was the Mossy Forest Park. Famous for its rare flora and fauna, the forest had a natural hiking trail environment suitable for outdoor enthusiasts. Cameron Highlands was also known for its fresh flowers and vegetables (Nasir et al., 2020). Variety of flowers and vegetables could be bought at a local market located in Kea Farm, Brinchang.

Although it remained as a favorite destination especially to local tourist, Cameron Highlands had often been reported for cases of landslides occurrences such in Figure 3. According to Nasidi et al. (2020), the land on Cameron Highlands were made up of two types of soil, mainly podzolic soil and lithosols soil. Yusoff et al. (2016) defined podzolic as type of soil with sandy texture, sensitive to severe degradation by human activities. Meanwhile, Vakilian (1978) defined lithosols as type of soil suitable for growing crops with adequate rainfall. Hadi et al. (2020) indicated that the surface of Cameron Highlands was made up of residual soil consisted of clay.

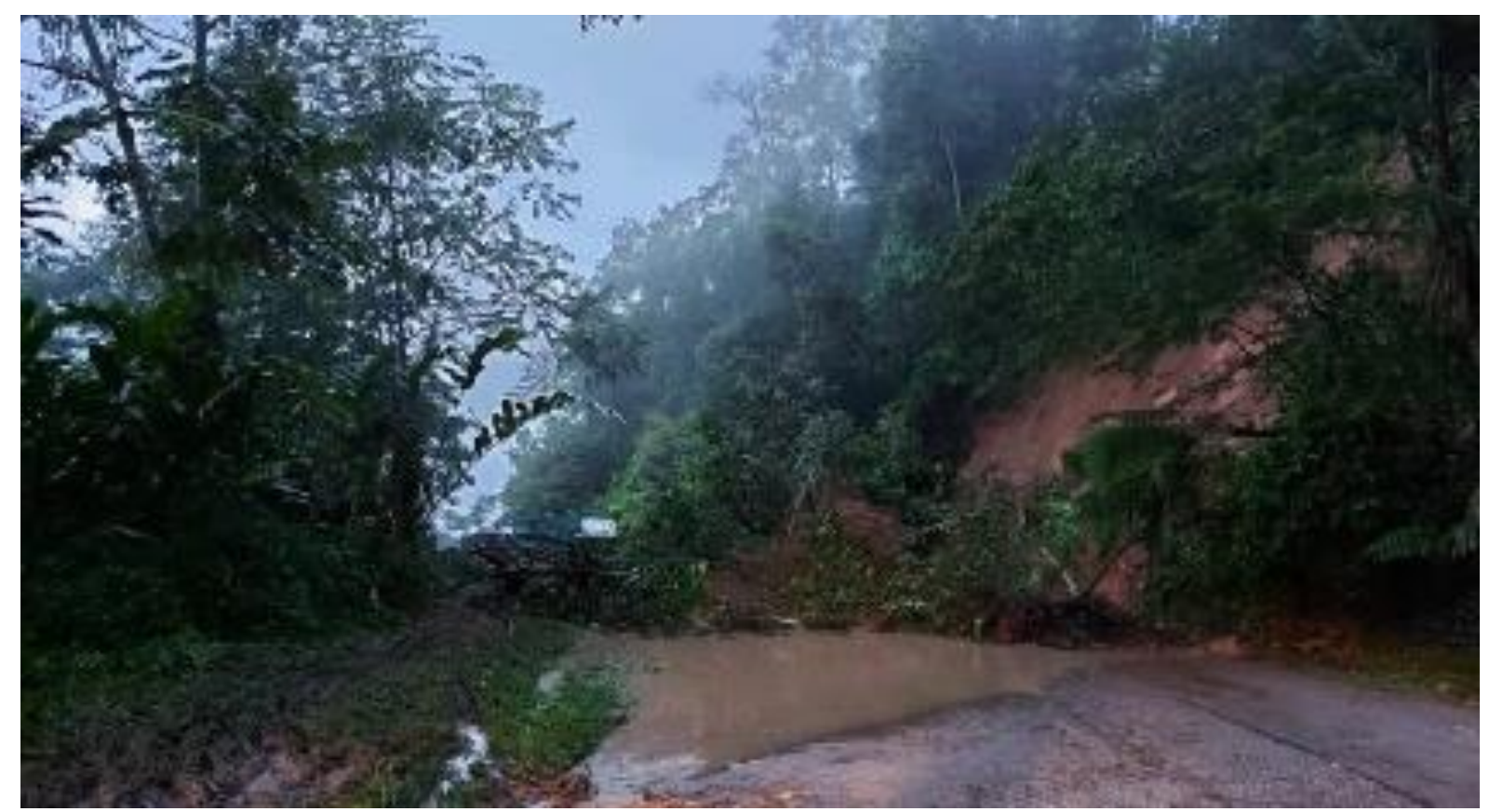

Figure 3. Landslide on October 2020 at Cameron Highlands

Hadi et al. (2020) described clay as a binder in maintaining the structure of residual soil. It was further discussed that the clay particles reacted to amount of water it was in contact with. Over exposure of clay with water would result in the form of clay to swell and became spongy. In this condition, the clay binder property would drop, thus weaken the structure of residual soil. The reduction of soil strength would lead to failure in slope stability, which resulted in landslide. This natural disaster was often reported in which an intense rainfall took place such as in Figure 3. 
When rainfall occurred, the rainwater would travel along the earth surface as runoff and penetrate into the soil in a process called infiltration. Excessive infiltration due to intense rainfall would lead clay particle in soil structure to swell, resulted in slope failure. A graph of Soil Water Characteristic Curve (SWCC) for granitic residual soil VI by Hadi et al. (2020) in Figure 4 was reviewed following to this phenomenon. Water content was referred as the amount of water contained in soil, measured in percentage (\%). While suction was the surface tension force due to capillary and adsorption forces, measured in kilopascal ( $\mathrm{kPa}$ ). Increased in suction resulted in more slope stability. Higher soil strength could be achieved with increased moisture content. The condition remained true until the water content reached $24.2 \%$, where the suction was $100 \mathrm{kPa}$, as the soil obtained its maximum strength, the slope would achieve its full stability. When more water was added, the soil started to weaken. This would lead to slope failure. Thus, moisture content analysis was required to evaluate the soil strength.

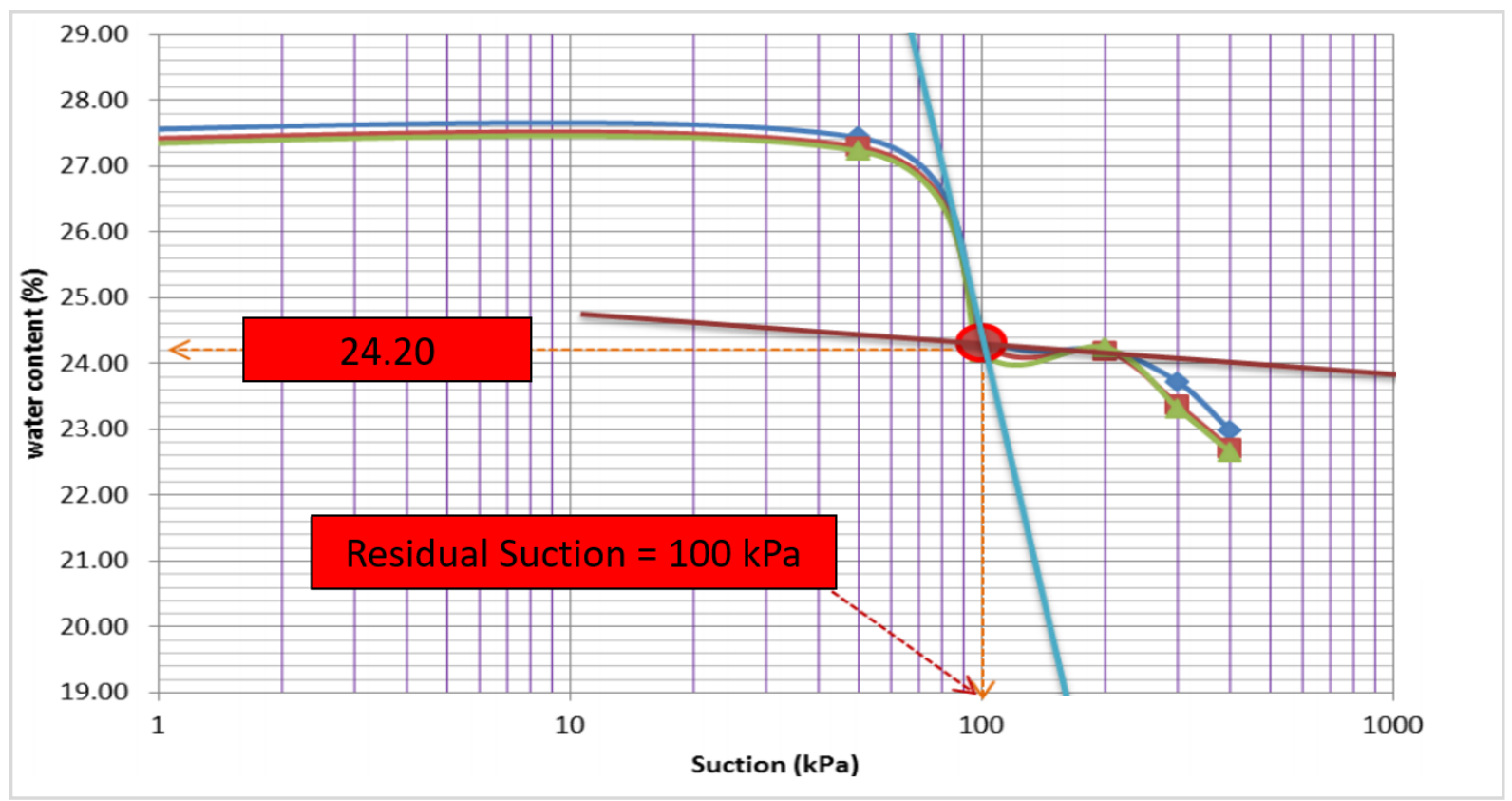

Figure 4. Soil Water Characteristic Curve (SWCC) for Granitic Residual Soil VI

(Source: B.A. Hadi, 2017)

\section{Methodology}

A previously landslide location was chosen for this research. The slope was situated at Jalan Kuala Terla, Kampung Raja, between the route of Simpang Pulai to Cameron Highlands. Depth of 0.2 to $0.5 \mathrm{~m}$ from surface of the slope were dug and samples of residual soil were collected as in Figure 5. 


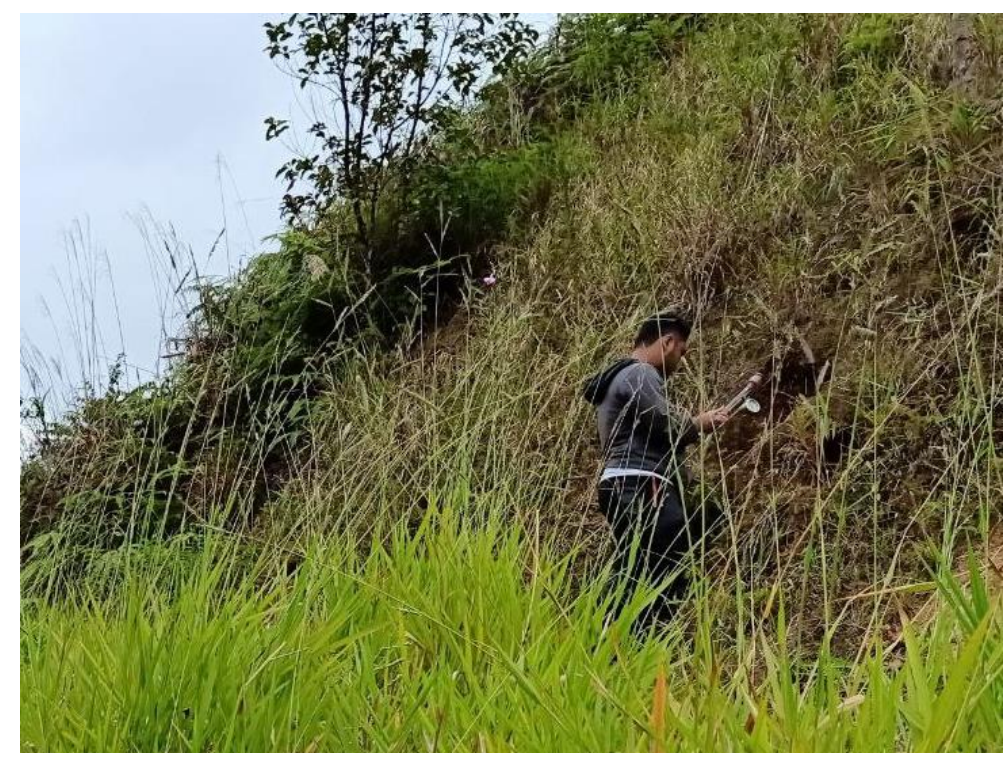

Figure 5. Process of collecting soil samples

The time and date of each sample were recorded, and their weight were measured using an electronic balance. The temperature and coordinates were also measured by utilizing a Weather software and Google Maps application on smartphone. The details were labelled on the soil samples collected as in Figure 6.

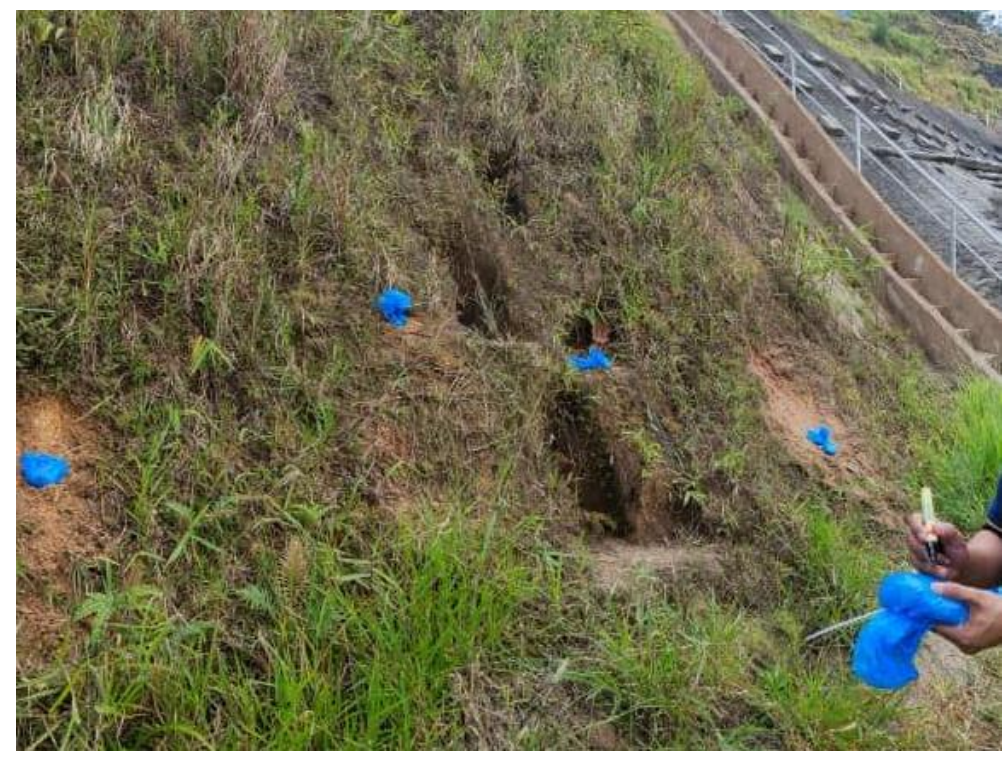

Figure 6. Process of labelling soil samples collected

With the coordinate of 4.5545730 latitude and 101.4125610 longitude, the samples were labelled in order of sequence, time, date and weight along with their surrounding temperature as in Table 1. 
Table 1. Labels for Residual Soil Samples Collected at Kampung Raja, Cameron Highlands

\begin{tabular}{|c|c|c|c|c|}
\hline Sample No. & Date & $\begin{array}{c}\text { Time } \\
(24-H r \text { Clock })\end{array}$ & $\begin{array}{c}\text { Weight } \\
(\mathrm{Kg})\end{array}$ & $\begin{array}{c}\text { Temperature } \\
\left({ }^{\circ} \mathrm{C}\right)\end{array}$ \\
\hline 1 & $31 / 10 / 2020$ & $10: 22$ & 0.250 & 17 \\
\hline 2 & $31 / 10 / 2020$ & $10: 27$ & 0.170 & 17 \\
\hline 3 & $31 / 10 / 2020$ & $10: 32$ & 0.205 & 17 \\
\hline 4 & $31 / 10 / 2020$ & $10: 37$ & 0.210 & 17 \\
\hline 5 & $31 / 10 / 2020$ & $10: 42$ & 0.110 & 18 \\
\hline 6 & $31 / 10 / 2020$ & $10: 47$ & 0.185 & 18 \\
\hline 7 & $31 / 10 / 2020$ & $10: 52$ & 0.220 & 18 \\
\hline 8 & $31 / 10 / 2020$ & $10: 56$ & 0.195 & 18 \\
\hline 9 & $31 / 10 / 2020$ & $11: 02$ & 0.200 & 18 \\
\hline 10 & $31 / 10 / 2020$ & $11: 14$ & 0.280 & 18 \\
\hline
\end{tabular}

The soil samples were brought to Geotechnical laboratory in UiTM Pulau Pinang and tested with moisture content analysis by oven-dry method in accordance with British Standard 1337: Part 2: 1990: 3.2. Containers were prepared and weighted. Then, soil samples with their individual containers were weighted. They were placed in an oven set at $105^{\circ} \mathrm{C}$ for 24 hours as in Figure 7 and later weighted again. The moisture contents of the soil samples were calculated. 
INTERNATIONAL JOURNAL OF ACADEMIC RESEARCH IN BUSINESS AND SOCIAL SCIENCES Vol. 11, No. 4, 2021, E-ISSN: 2222-6990 @ 2021 HRMARS

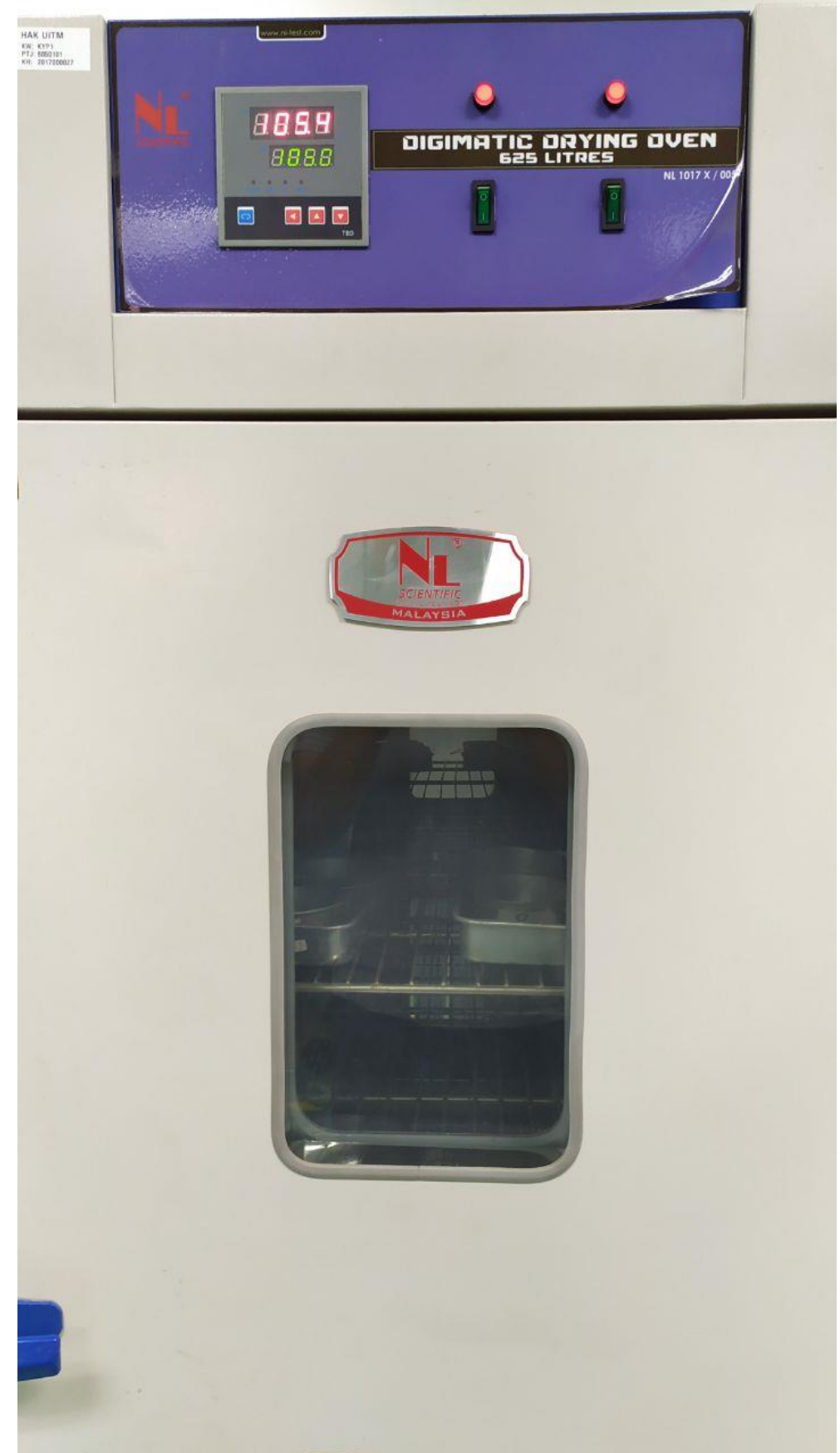

Figure 7. Soil samples and containers put in an oven for oven-dry process 


\section{Results and Analysis}

Table 2. Moisture Content Analysis for Soil Samples from Kampung Raja, Cameron Highlands

\begin{tabular}{|c|c|c|c|c|}
\hline \multirow{2}{*}{ Sample No. } & \multicolumn{3}{|c|}{ Weight (g) } & \multirow{2}{*}{$\begin{array}{c}\text { Moisture } \\
\text { Content } \\
\text { ny) }\end{array}$} \\
\cline { 2 - 4 } & Container, $\mathrm{m}_{1}$ & $\begin{array}{c}\text { Container }+ \\
\text { Wet Soil, } \mathrm{m}_{2}\end{array}$ & $\begin{array}{c}\text { Container }+ \\
\text { Dry Soil, } \mathrm{m}_{3}\end{array}$ & 24.8 \\
\hline 1 & 14.24 & 128.96 & 106.15 & 25.7 \\
\hline 2 & 13.49 & 101.74 & 83.72 & 25.7 \\
\hline 3 & 15.04 & 142.30 & 116.26 & 28.8 \\
\hline 4 & 19.95 & 101.73 & 83.45 & 32.9 \\
\hline 5 & 21.47 & 84.08 & 68.59 & 24.6 \\
\hline 6 & 20.23 & 93.99 & 79.42 & 25.6 \\
\hline 7 & 15.19 & 98.78 & 81.77 & 24.1 \\
\hline 8 & 19.81 & 72.58 & 62.32 & 38.5 \\
\hline 9 & 21.39 & 47.65 & 40.35 & 25.1 \\
\hline 10 & 21.58 & 55.14 & 48.41 & \\
\hline
\end{tabular}

Table 2 shows the result obtained from moisture content analysis. Based on the table, the maximum moisture content obtained was $38.5 \%$ while the minimum moisture content was $24.1 \%$. The average moisture content acquired from the analysis was $27.6 \%$. These results were evaluated with the existing model of Soil Water Characteristic Curve in Figure 4.

Based on Figure 4, the strength of soil reduced as the amount of water percentage of soil surpassed its optimum moisture content. Since the average moisture content of samples collected from Kampung Raja exceeded the optimum moisture content of residual soil $27.6 \%$ $>24.2 \%)$, the location of slope where samples were collected had weaken soil strength.

\section{Conclusion}

The objectives of this research were met. Residual soil samples from a landslide location were collected, and the details were labelled and tabulated. Moisture content analysis was conducted, and the average moisture content of the soil obtained was $27.6 \%$. Evaluation of the results concluded that the residual soil collected from site had weak soil strength, thus held risk for failure of landslide.

\section{Acknowledgement}

The authors would like to acknowledge Ministry of Higher Education Malaysia (MOHE) for the financial support on this research through Fundamental Research Grant Scheme (FRGS) with reference code FRGS/1/2018/TK08/UITM/02/03 which made this crucial research possible.

\section{References}

Aziz, A., Ajuhari, Z., Bidin, S., Nahar, S. S., \& Yaakob (2020). Re-Development of Mossy Forest Park in Cameron Highlands, Pahang: A Case Study for Preparing a Master Plan. Ecotourism in Malaysia: Current Scenario. 14-24.

Hadi, B. A., Noor, M. J. M., Ibrahim, A., Ismail, B. N., Ahmad, J., \& Zakariah, Z. (2020). The Effect of Soaking on Shear Strength of a Malaysian Granitic Residual Soil. International 
Conference on Civil and Environmental Engineering IOP Conference Series: Earth and Environmental Science. 476012049.

Rosman, R. (2020). Hindrance on Jalan Tapah - Cameron Highlands due to Landslide. Harian Metro. Retrieved from shorturl.at/wxBT1

Maturidi, A. M. A. M., Kasim, N., Taib, K. A., Azahar, W. N. A. W., \& Husain, N. M. H. (2020). Rainfall-Induced Landslides in Cameron Highland Area, Malaysia. International Conference on Technology, Engineering and Sciences (ICTES) 2020. 012019

Nasidi, N. M., Wayayok, A., Abdullah, A. F., \& Kassim, M. S. M. (2020). Vulnerability of Potential Soil Erosion and Risk Assessment at Hilly Farms using InSAR Technology. Algerian Journal of Engineering and Technology.

Nasir, N. F., Nasir, M. A., Nasir, M. N. F., \& Nasir, M. F. (2020). Understanding of Domestic Tourism in Malaysia: A Qualitative Study. International Research Journal of Modernication in Engineering Technology and Science. 2(9).

Pua, F. L., Subari, M. S., Ean, L. W., \& Krishnan, S. G. (2020). Characterization of Biomass Fuel Pellets Made from Malaysia Tea Waste and Oil Palm Empty Fruit Bunch. Materials Today: Proceedings, 31(1), 187-190.

Vakilian, M. (1978). Soils-Resource Data for Agricultural Development. Hawaii Agricultural Experiment Station.

Yusoff, K. H. M., Abdu, A., Sakurai, K., Tanaka, S., \& Kang, Y. (2017). Influence of agricultural activity on soil morphological and physicochemical properties on sandy beach ridges along the east coast of Peninsular Malaysia. Social Science and Plant Nutrition. 63(1). 55-66. 